\title{
Pengaruh Kepemimpinan, Budaya Organisasi dan Motivasi Terhadap Kualitas Pelayanan Kepada Pelanggan PT. Hadeka Primantara
}

\author{
Aditya Putra Kusuma \\ Sekolah Tinggi Ilmu Ekonomi Tribuana \\ glukosa88lagi@gmail.com
}

\begin{abstract}
This study aims to determine (1) The influence of leadership on motivation. (2) The influence of organizational culture on motivation. (3) The influence of motivation on service quality. (4) The influence of leadership on service quality (5) The influence of organizational culture on service quality. This research uses saturated sampling technique. The population of this research is all employees of PT. Hadeka Primantara which amounted to 91 people. Research method in this research is quantitative research method by using computer program Partial Least Square (PLS) and Structural Equation Modeling (SEM). This thesis uses quantitative research through survey methods, interviews and questionnaires. The results showed significant influence Leadership on Motivation at PT. Hadeka Primantara with the value of T Statistics 4,818 $\geq 1.96$. There is a significant influence Organizational Culture on Motivation at PT. Hadeka Primantara with the value of T Statistics 10,435 $\geq 1.96$. There is no significant influence Motivation on Service Quality at PT. Hadeka Primantara with the value of T Statistics $0.095 \leq 1.96$. There is no significant effect of Leadership on Service Quality at PT. Hadeka Primantara with the value of T Statistics $0.677 \leq 1.96$. There is significant influence of Organization Culture on Quality of Service with value of T Statistics 2,402 $\leq 1.96$.
\end{abstract}

Keyword: Leadership, Organizational Culture, Motivation, Quality of Service

\section{Abstrak}

Penelitian ini bertujuan untuk mengetahui (1) Pengaruh kepemimpinan terhadap motivasi. (2) Pengaruh budaya organisasi terhadap motivasi. (3) Pengaruh motivasi terhadap kualitas pelayanan. (4)Pengaruh kepemimpinan terhadap kualitas pelayanan.(5) Pengaruh budaya organisasi terhadap kualitas pelayanan. Penelitian ini menggunakan teknik sampling jenuh. Populasi penelitian ini adalah seluruh karyawan PT. Hadeka Primantara yang berjumlah 91 orang. Metode penelitian dalam penelitian ini adalah metode penelitian kuantitatif dengan menggunakan program komputer Partial Least Square (PLS) dan Structural Equation Modeling (SEM). Tesis ini menggunakan penelitian kuantitatif melalui metode survey, wawancara dan kuesioner.Hasil penelitian menunjukkan pengaruh yang signifikan Kepemimpinan terhadap Motivasi pada PT. Hadeka Primantara dengan nilai T Statistics $4,818 \geq 1.96$. Terdapat pengaruh yang signifikan Budaya Organisasi terhadap Motivasi pada PT. Hadeka Primantara dengan nilai T Statistics 10,435 $\geq$ 1.96. Tidak terdapat pengaruh yang signifikan Motivasi terhadap Kualitas Pelayanan pada PT. Hadeka Primantara dengan nilai T Statistics 0,095 $\leq 1.96$. Tidak terdapat pengaruh yang signifikan Kepemimpinan terhadap Kualitas Pelayanan pada PT. Hadeka Primantara dengan nilai T Statistics 0,677 $\leq 1.96$. Terdapat pengaruh yang signifikan Budaya Organisasi terhadap Kualitas Pelayanan dengan nilai T Statistics $2,402 \leq 1.96$.

Kata Kunci: Kepemimpinan, Budaya Organisasi, Motivasi, Kualitas Pelayanan 


\section{PENDAHULUAN}

PT. Hadeka Primantara memiliki lebih dari 20 tahun pengalaman dalam bidang industry machining and engineering. PT. Hadeka Primantara adalah perusahaan yang bergerak di bidang manufacturing press parts, dies, jigs, machinery and construction. Produkproduk PT. Hadeka Primantara dibuat dengan kualitas inspeksi dan sistem yang kuat. Pada 23 September 2004 PT. Hadeka Primantara menerima sertifikasi ISO 9001.2000 (Sertifikat NO. 11369) sebagai bukti konsistensi dalam menjaga kualitas produk dan sistemnya. Visi dari perusahaan adalah menjadi perusahaan sehat yang mampu bersaing di tingkat nasional di bidang machinery dan industry. Sedangkan misi dari perusahaan demi suksesnya para stakeholder perusahaan melalui pertumbuhan pembangunan dan para supplier bagian komponen-komponen mesin dengan tingkat persaingan nasional di pasar Indonesia. Perusahaan akan memberikan kontribusi kesuksesan bagi anggotanya dengan cara mengidentifikasi dan mengembangkan peluang pasar untuk pertumbuhan dan mendapatkan keuntungan serta membangun strategi yang kompetitif dalam pasar lokal melalui kualitas, pelayanan dan harga yang ditawarkan.
Memimpin suatu perusahaan dengan berbagai sifat, karakter karyawannya tidaklah mudah. Keberhasilan serta kegagalan pasti dialami oleh pemimpin perusahaaan. Terlebih krisis Tahun 19891990 membuat pimpinan PT. Hadeka Primantara harus berusaha lebih keras agar perusahaan tidak gulung tikar.Peran pemimpin perusahaan selain memberikan arahan dan memberikan contoh dalam bertingkah laku di dalam perusahaan yang dikenal sebagai budaya organisasi. Akar setiap budaya organisasi adalah serangkaian karakteristik ini yang dihargai secara kolektif oleh anggota organisasi.

Kurangnya loyalitas yang diberikan karyawan kepada perusahaan. Karyawan yang absen karena sakit dan ijin diperbolehkan karena memberikan keterangan yang jelas mengapa seorang karyawan tersebut tidak hadir. Namun yang terjadi apabila karyawan terlambat masuk bahkan alpa mengakibatkan karyawan mendapatkan teguran dari pimpinan perusahaan karena melanggar budaya organisasi yang diterapkan perusahaan.

Budaya Organisasi mencerminkan persepsi umum yang dilakukan oleh seluruh anggota organisasi. Karenanya dapat diharapkan bahwa individu dengan latar belakang berbeda atau tingkat yang berbeda dalam organisasi akan cenderung 
menjelaskan budaya organisasi dengan terminologi yang sama. Permasalahan dalam budaya organisasi yaitu tidak semua budaya organisasi yang ada di suatu perusahaan dapat diterima dan dilaksanakan dengan baik oleh seluruh anggota organisasi terbukti dalam beberapa permasalahan budaya organisasi yang ada di PT. Hadeka Primantara.

Budaya organisasi mempengaruhi motivasi yang diberikan oleh pemimpin kepada karyawan dalam perusahaan. Menurut Edy Sutrisno (2015:109)[1] adalah suatu faktor yang mendorong seseorang untuk melakukan suatu aktifitas tertentu, oleh karena itu motivasi seringkali diartikan pula sebagai faktor pendorong perilaku seseorang. Perusahaan mempunyai motivasi yang berbeda-beda untuk mendorong karyawan melaksanakan tugasnya dengan baik. Sesuai dengan hasil wawancara yang dilakukan dengan Manajer di PT. Hadeka Primantara motivasi yang diberikan diantaranya : Pertama, pimpinan yang loyalitas terhadap perusahaan dalam kurun waktu lebih dari tiga (3) tahun akan diberikan fasilitas kendaraan berupa motor dan mobil dengan melihat fungsionalnya dan diberikan kompensasi berupa uang sesuai dengan jabatannya di perusahaan. Kedua, karyawan yang mempunyai loyalitas tinggi serta keahlian akan diberikan tunjangan menurut keahliannya.

PT. Hadeka Primantara sebagai perusahaan yang bergerak bagian press manufaktur, mesin dan konstruksi. Pada saat ini tingkat loyalitas dari customer semakin membaik, namun beberapa masih mengalami keburukan karena banyaknya komplain dari pelanggan. Sehubungan dengan maksud peneliti ingin mengetahui seberapa baik kualitas pelayanan yang ada di PT. Hadeka Primantara, berikut beberapa komplain dari pelanggan atau customer atas kualitas pelayanan yang diberikan oleh perusahaan diantaranya mengenai ketidak sesuaian barang dengan permintaan pelanggan/customer, barang yang dihasilkan NG atau Not Good serta keterlambatan pengiriman barang dari perusahaan kepada pelanggan tidak sesuai dengan waktu yang telah disepakati.

Untuk mengetahui lebih lanjut, berikut pengertian pengertian dari setiap variabel yang diteliti. Anoraga (1992) yang dikutip Edy Sutrisno (2017:214)[2],mengemukakan bahwa kepemimpinan adalah kemampuan untuk mempengaruhi pihak lain, melalui komunikasi baik langsung maupun tidak langsung dengan maksud untuk menggerakkan orang-orang agar dengan penuh pengertian, kesadaran dan senang hati bersedia mengikuti kehendak 
pimpinan itu. Menurut Gary Yukl (Emron Edison,dkk, 2017:87)[3] Kepemimpinan adalah proses mempengaruhi orang lain untuk memahami dan setuju dengan apa yang perlu dilakukan dan bagaimana tugas itu dilakukan secara efektif, serta proses memfasilitasi upaya individu dan kolektif untuk mencapai tujuan bersama.

Jono M Munandar (Mulyadi, 2016:16)[4] Budaya Organisasi adalah sistem makna dan keyakinan bersama dalam organisasi yang menetukan pada kadar yang tinggi, cara karyawan bertindak. Budaya organisasi merupakan hasil proses melebur gaya budaya dan atau perilaku tiap individu yang dibawa sebelumnya ke dalam sebuah normanorma dan filosofi baru, yang memiliki energi serta kebanggan kelompok dalam menghadapi sesuatu dan tujuan tertentu. Jerome Want (Wibowo, 2013:18-19)[5], menyatakan bahwa budaya organisasi adalah sebuah sistem keyakinan kolektif yang dimiliki orang dalam organisasi tentang kemampuan mereka bersaing di pasar, dan bagaimana mereka bertindak dalam sistem keyakinan tersebut untuk memberikan nilai tambah produk dan jasa di pasar (pelanggan) sebagai imbalan atas penghargaan finansial. Budaya organisasi diungkapkan melalui sikap, sistem, keyakinan, impian, perilaku, nilai-nilai, tata cara dari perusahaan, dan terutama melalui tindakan serta kinerja pekerja dan manajemen.

Motivasi didevinisikan oleh Fillmore H. Stanford (Anwar Prabu Mangkunegara, 2001:93)[6] bahwa "Motivation as an energizing condition of the organism that serves to direct that organism toward the goal of a certain class" (Motivasi sebagai suatu kondisi yang menggerakkan manusia kearah suatu tujuan tertentu. Karena sangat luasnya ranah motivasi dala peri kehidupan manusia maka untuk memahami motivasi perlulah dipahami asumsi dasar motivasi. Stoner (Sentot Imam Wahjono, 2010:79)[7] mengatakan bahwa terdapat empat asumsi dasar motivasi yaitu :

1. Motivasi adalah hal-hal yang baik, seseorang menjadi termotivasi karena dipuji atau sebaliknya bekerja dengan penuh motivasi dan karenanya seorang dipuji.

2. Motivasi adalah satu dari beberapa faktor yang menentukan prestasi kerja seseorang, faktor yang lain adalah kemampuan, sumber daya, kondisi tempat kerja, kepemimpinan, dan lain-lain.

3. Motivasi bisa habis dan perlu ditambah suatu waktu, seperti pada beberapa faktor psikologis yang lain bersifat siklikal, maka pada saat berada pada titik terendah motivasi perlu ditambah. 
4. Motivasi adalah alat yang dapat dipakai manajemen untuk mengatur hubungan pekerjaan dalam organisasi.

Kualitas pelayanan adalah totalitas fitur dan karakteristik produk atau jasa yang bergantung pada kemampuannya untuk memuaskan kebutuhan yang dinyatakan atau tersirat. (Yusuf et al., 2022). Pengertian lain menyatakan bahwa kualitas pelayanan adalah sebagai tingkat keunggulan yang diharapkan dan pengendalian atas tingkat keunggulan tersebut untuk memenuhi keinginan pelanggan (Jurnal Reza Dimas Sigit, 2014 :1)[8]. Colgate dan Danaher (Jurnal Reza Dimas Sigit (2014:5)[9] mengemukakan bahwa kualitas pelayanan keryawan terhadap pelanggan berpengaruh secara asimetris terhadap kepuasan pelanggan, dimana pelayanan yang buruk berakibat lebih besar terhadap kepuasan pelanggan daripada pelayanan yang dikategorikan baik. Implementasi strategi dengan kategori terbaik akan meningkatkan kepuasan dan kesetiaan pelanggan lebih besar daripada tidak ada pemasaran yang relasional yang dilakukan. Dan sebaliknya, implementasi strategi dengan kategori terburuk akan menurunkan kepuasan dan kesetiaan pelanggan lebih besar daripada tidak ada pemasaran yang relasional yang dilakukan.
Berdasarkan uraian di atas mengenai Kepemimpinan, Budaya Organisasi, Motivasi dan Kualitas Pelayanan, maka peneliti tertarik untuk melakukan penelitian dan menguraikannya menjadi tesis yang berjudul "Pengaruh Kepemimpinan, Budaya Organisasi, Motivasi terhadap Kualitas Pelayanan kepada Pelanggan PT. Hadeka Primantara".

\section{Tujuan Penelitian}

Sesuai dengan latar belakang masalah dan rumusan masalah, maka tujuan penelitian ini adalah sebagai berikut:

1. Untuk mengetahui seberapa besar pengaruh kepemimpinan terhadap motivasi.

2. Untuk mengetahui seberapa besar pengaruh budaya organisasi terhadap motivasi.

3. Untuk mengetahui seberapa besar pengaruh motivasi terhadap kualitas pelayanan.

4. Untuk mengetahui seberapa besar pengaruh kepemimpinan terhadap kualitas pelayanan.

5. Untuk mengetahui seberapa besar pengaruh budaya organisasi terhadap kualitas pelayanan. 


\section{Kerangka Berpikir}

Kerangka berpikir dalam penelitian ini dijelaskan adanya ubungan ataupun pengaruh Kepemimpinan, Budaya Organisasi dan Motivasi terhadap Kualitas Pelayanan kepada Pelanggan PT. Hadeka Primantara dapat di gambarkan sebagai berikut:

\section{Gambar 1.1 Kerangka Berpikir}

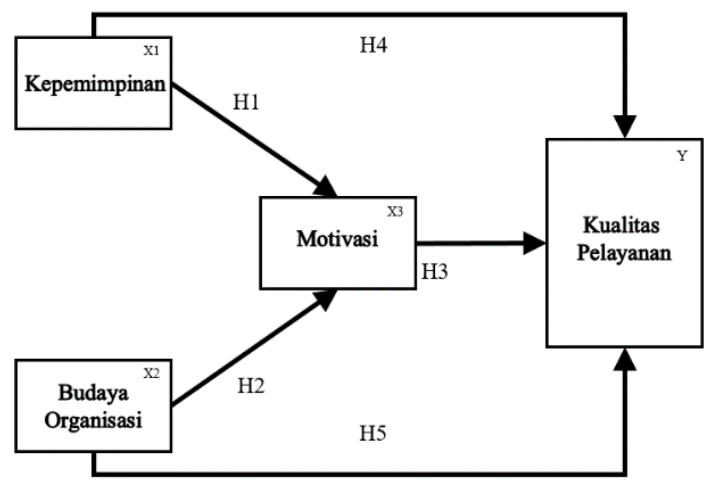

Hipotesis dalam penelitian ini dirumuskan sebagai berikut :

H1 : Diduga terdapat pengaruh yang signifikan atas kepemimpinan terhadap motivasi.

H2 : Diduga terdapat pengaruh yang signifikan atas budaya organisasi terhadap motivasi.

H3 : Diduga terdapat pengaruh yang signifikan atas motivasi sebagai variabel intervening terhadap kualitas pelayanan.

H4 : Diduga terdapat pengaruh yang signifikan atas kepemimpinan terhadap kualitas pelayanan.
H5 : Diduga terdapat pengaruh yang signifikan atas budaya organisasi terhadap kualitas pelayanan.

\section{METODE PENELITIAN}

Metode penelitian kuantitatif akan digunakan dalam penelitian ini. Penelitian kuantitatif memusatkan perhatiannya pada gejala yang mempunyai karakteristik tertentu yang bervariasi dalam kehidupan manusia, yang dinamakan variabel. (Marpaung, 2021). Penelitian kuantitatif berfokus pada variabel, bahkan sebelum penelitian dilakukan telah ditentukan terlebih dahulu variabel yang akan diteliti. Metode penelitian dalam penelitian ini adalah metode penelitian kuantitatif dengan menggunakan program komputer Partial Least Square (PLS) dan Structural Equation Modeling (SEM). Teknik pengumpulan data yang digunakan dalam penelitian ini adalah dengan Metode Survei. Penelitian dilaksanakan di PT. Hadeka Primantara, yang beralamat di JL.Perjuangan Kampung Penggilingan Baru Kel. Harapan Baru, Bekasi Utara, Kota Bekasi 17123. Waktu penelitian dilasanakan selama 3 (tiga) bulan dari Maret-Mei 2018. Dalam penelitian ini, populasi dan sampel yang diambil adalah seluruh karyawan yang ada di PT. Hadeka Primantara berjumlah 91 (sembilan puluh satu) orang. 


\section{HASIL DAN PEMBAHASAN}

Pengujian signifikan tidaknya pengaruh dari setiap variabel eksogen (variabel independen) terhadap variabel endogen (variabel dependen) dilakukan dengan cara membandingkan nilai $t$ statistik dengan $\mathrm{t}$ tabel. Nilai $\mathrm{t}$ tabel untuk pengujian hipotesis penelitian ini ditentukan dengan uji dua sisi dengan $\alpha=$ $5 \%$, diperoleh nilai $\mathrm{t}$ tabel sebesar 1,96.
Apabila nilai $\mathrm{t}$ statistik $>\mathrm{t}$ tabel maka terbukti terdapat pengaruh signifikan antara variabel eksogen ke endogen, sebaliknya apabila nilai $\mathrm{t}$ statistik < tabel tabel maka terbukti tidak terdapat pengaruh signifikan antara variabel eksogen ke endogen. Hasil t statistik dapat dilihat pada tabel dibawah ini:

Tabel 3.1 Hasil Uji Hipotesis

\begin{tabular}{|c|c|c|c|c|c|c|}
\hline Hipotesis & $\begin{array}{c}\text { Pengaruh antar } \\
\text { Variabel }\end{array}$ & $\begin{array}{c}\text { Path } \\
\text { Koefisien }\end{array}$ & $\begin{array}{c}\text { Besar } \\
\text { Pengaruh }\end{array}$ & $\begin{array}{c}\boldsymbol{T} \\
\text { Statistics }\end{array}$ & $\begin{array}{c}\text { T } \\
\text { Tabel }\end{array}$ & Putusan \\
\hline H1 & $\begin{array}{c}\text { Kepemimpinan } \rightarrow \\
\text { Motivasi }\end{array}$ & 0.316 & $31.6 \%$ & 4,818 & 1,96 & Signifikan \\
\hline H2 & $\begin{array}{c}\text { Budaya Organisasi } \rightarrow \\
\text { Motivasi }\end{array}$ & 0.671 & $67.1 \%$ & 10,435 & 1,96 & Signifikan \\
\hline H3 & $\begin{array}{c}\text { Motivasi } \rightarrow \text { Kualitas } \\
\text { Pelayanan }\end{array}$ & 0.021 & $2.1 \%$ & 0.095 & 1,96 & Tidak signifikan \\
\hline H4 & $\begin{array}{c}\text { Kepemimpinan } \rightarrow \\
\text { Kualitas Pelayanan }\end{array}$ & 0.118 & $11.8 \%$ & 0.677 & 1,96 & Tidak signifikan \\
\hline H5 & $\begin{array}{c}\text { Budaya Organisasi } \rightarrow \\
\text { Kualitas Pelayanan }\end{array}$ & 0.630 & $63 \%$ & 2,402 & 1,96 & Signifikan \\
\hline
\end{tabular}

3.1 Pengaruh Kepemimpinan (X1) terhadap Motivasi (X3)

Pengujian hipotesis pertama dilakukan untuk mengetahui pengaruh Kepemimpinan (X1) terhadap Motivasi (X3). Pembuktian ada tidaknya pengaruh signifikan dilakukan dengan perbandingan nilai t-statistik hasil dari bootstrapping dengan t-tabel. Berdasarkan tabel 4.13, diketahui bahwa nilai t-statistik lebih besar dari nilai t-tabel yaitu 4,818 lebih besar dari 1,96. Dapat disimpulkan bahwa variabel Kepemimpinan (X1) terbukti signifikan terhadap variabel Motivasi (X3) pada taraf signifikan 5\%, dengan besaran pengaruh 31,6\%. Koefisien arah hubungan berbentuk positif sedangkan pola hubungan yang terbentuk bersifat positif artinya semakin baik Kepemimpinan maka akan semakin baik pula Motivasi yang diberikan pemimpin dengan besar pengaruh $31,6 \%$. Penelitian ini relevan dengan penelitian yang dilakukan Evi Wahyuni dan Sarly Sariadi yang 
menyatakan bahwa Gaya Kepemimpinan signifikan terhadap Motivasi Kerja.

\subsection{Pengaruh Budaya Organisasi} (X2) terhadap Motivasi (X3)

Pengujian hipotesis kedua dilakukan untuk mengetahui pengaruh Budaya Organisasi (X2) terhadap Motivasi (X3). Pembuktian ada tidaknya pengaruh signifikan dilakukan dengan perbandingan nilai t-statistik hasil dari bootstrapping dengan t-tabel. Berdasarkan tabel 4.13, diketahui bahwa nilai t-statistik lebih besar dari nilai t-tabel yaitu 10,435 lebih besar dari 1,96. Dapat disimpulkan bahwa variabel Budaya Organisasi (X2) terbukti signifikan terhadap variabel Motivasi (X3) pada taraf signifikan 5\%, dengan besaran pengaruh $67,1 \%$. Koefisien arah hubungan berbentuk positif sedangkan pola hubungan yang terbentuk bersifat positif artinya semakin baik Budaya Organisasi maka akan semakin baik pula Motivasi dengan besar pengaruh $31,6 \%$.

Penelitian ini relevan dengan teori yang dikemukakan oleh Robbins \& Coulter (2009) dan Pearce \& Robinson (2008) dalam bukunya Emron Edison, Yohny Anwar, dan Imas Komariyah (2017:180)[10], budaya memengaruhi cara anggota bertindak. Ini menggambarkan bahwa mereka yang bekerja dalam budaya organisasi yang kuat memiliki kenyamanan dan kebebasan dalam bertindak dalam arti yang positif, tentunya ini akan menimbulkan kepuasan, komitmen, dan motivasi yang lebih tinggi.

\subsection{Pengaruh Motivasi}

(X3)

\section{terhadap Kualitas Pelayanan (Y)}

Pengujian hipotesis yang ketiga dilakukan untuk mengetahui pengaruh Motivasi (X3) terhadap Kualitas Pelayanan (Y). Cara membuktikan ada tidaknya pengaruh yang signifikan dilakukan dengan membandingkan nilai tstatistik hasil dari bootstrapping dengan ttabel. Berdasarkan tabel 4.13, diketahui bahwa nilai t-statistik lebih kecil dari nilai t-tabel yaitu 0,095 lebih kecil dari 1,96. Dapat disimpulkan bahwa variabel Motivasi (X3) terbukti tidak signifikan terhadap variabel Kualitas Pelayanan (Y) pada taraf signifikan 5\%, dengan besaran pengaruh $2,1 \%$. Koefisien arah hubungan berbentuk positif sedangkan pola hubungan yang terbentuk bersifat positif artinya semakin baik Motivasi maka akan semakin baik pula Kualitas Pelayanan dan begitu sebaliknya jika Motivasi rendah maka akan menurunkan Kualitas Pelayanan dengan besar pengaruh $2,1 \%$.

Hasil penelitian ini tidak sesuai dengan penelitian sebelumnya dari Sastra Tamami yang menyebutkan bahwa terdapat pengaruh positif gaya kepemimpinan dan motivasi terhadap kualitas pelayanan dan kinerja pegawai. 


\subsection{Pengaruh Kepemimpinan (X1) terhadap Kualitas Pelayanan (Y)}

Pengujian hipotesis yang ketiga dilakukan untuk mengetahui pengaruh Kepemimpinan (X1) terhadap Kualitas Pelayanan (Y). Cara membuktikan ada tidaknya pengaruh yang signifikan dilakukan dengan membandingkan nilai tstatistik hasil dari bootstrapping dengan ttabel. Berdasarkan tabel 4.13, diketahui bahwa nilai t-statistik lebih kecil dari nilai t-tabel yaitu 0,677 lebih kecil dari 1,96. Dapat disimpulkan bahwa variabel Kepemimpinan (X1) terbukti tidak signifikan terhadap variabel Kualitas Pelayanan (Y) pada taraf signifikan 5\%, dengan besaran pengaruh $11,8 \%$. Koefisien arah hubungan berbentuk positif sedangkan pola hubungan yang terbentuk bersifat positif artinya semakin baik Kepemimpinan maka akan semakin baik pula Kualitas Pelayanan dan begitu sebaliknya jika Kepemimpinan rendah maka akan menurunkan Kualitas Pelayanan dengan besar pengaruh 2,1\%.

Penelitian ini tidak sesuai dengan penelitian sebelumnya dari Sastra Tamami yang menyebutkan bahwa terdapat pengaruh positif gaya kepemimpinan dan motivasi terhadap kualitas pelayanan dan kinerja pegawai.
3.5 Pengaruh Budaya Organisasi (X2) terhadap Kualitas Pelayanan (Y)

Pengujian hipotesis terakhir atau kelima dilakukan untuk mengetahui pengaruh Budaya Organisasi (X2) terhadap Kualitas Pelayanan (Y). Pembuktian ada tidaknya pengaruh signifikan dilakukan dengan perbandingan nilai t-statistik hasil dari bootstrapping dengan t-tabel. Berdasarkan tabel 4.13, diketahui bahwa nilai t-statistik lebih besar dari nilai t-tabel yaitu 2,402 lebih besar dari 1,96. Dapat disimpulkan bahwa variabel Budaya Organisasi (X2) terbukti signifikan terhadap variabel Kualitas Pelayanan (Y) pada taraf signifikan 5\%, dengan besaran pengaruh $63 \%$. Koefisien arah hubungan berbentuk positif sedangkan pola hubungan yang terbentuk bersifat positif artinya semakin baik Budaya Organisasi maka akan semakin baik pula Kualitas Pelayaan yang diberikan kepada pelanggan dengan besar pengaruh $31,6 \%$.

Penelitian ini sesuai dengan salah satu teori yang menyatakan bahya Budaya organisasi yang kuat mendukung tujuantujuan perusahaan, sebaliknya yang lemah atau negatif menghambat atau bertentangan dengan tujuan-tujuan perusahaan. Dalam suatu perusahaan yang budaya organisasinya kuat, nilai-nilai bersama dipahami secara mendalam, 
dianut, dan diperjuangkan oleh sebagian besar para anggota organisasi (karyawan perusahaan) dalam bukunya Edy Sutrisno (2015:21)[11]. Tujuan-tujuan perusahaan yang dimaksud salah satunya adalah Kualitas Pelayanan yang baik.

Output Pengujian lainnya terhadap model dilakukan dengan melihat nilai $\mathrm{R}$ Square yang merupakan uji Goodness Of fit (GOF) model yang dapat dilihat pada tabel 3.2 sebagai berikut:

\section{Hasil $R$ Square}

\begin{tabular}{|l|c|}
\hline & R Square \\
\hline Kualitas Pelayanan & 0,583 \\
\hline
\end{tabular}

Sumber: Diolah dari PLS

Nilai R Square sebesar 0,583, dapat dijelaskan bahwa pengaruh Variabel Kepemimpinan (X1), Budaya Organisasi (X2) dan Motivasi (X3) terhadap Kualitas Pelayanan (Y) memberi nilai sebesar 0,583 yang dapat diinterpretasikan bahwa variabel Kualitas Pelayanan dapat dijelaskan oleh variabel Kepemimpinan, Budaya Organisasi dan Motivasi sebesar $58,3 \%$. Sedangkan sisanya $41,7 \%$ dijelaskan oleh variabel lain diluar yang diteliti.

\section{PENUTUP}

\section{Simpulan}

$\begin{array}{lll}\text { Berdasarkan } & \text { analisis dan } \\ \text { pembahasan, maka kesimpulan dari } & \\ \text { penelitian ini adalah sebagai berikut: }\end{array}$

1. Terbukti signifikan variabel Kepemimpinan (X1) terhadap variabel Motivasi (X3). Kinerja terbaik yang diberikan oleh Pimpinan berpengaruh signifikan dengan tingginya motivasi yang diperoleh bagi karyawan jika dilihat dari distribusi jawaban responden atas pernyataan dalam kuesioner penelitian.

2. Terbukti signifikan variabel Budaya Organisasi (X2) terhadap variabel Motivasi (X3). Para pegawai dapat bekerja sama dengan baik dalam tim dan pimpinan memberikan apresiasi tertinggi sebagai motivasi bagi karyawannya menjadikan budaya organisasi berpengaruh signifikan terhadap motivasi jika dilihat dari distribusi jawaban responden atas pernyataan dalam kuesioner penelitian.

3. Terbukti tidak signifikan variabel Motivasi (X3) terhadap variabel Kualitas Pelayanan (Y). Dengan ketidaknyamanan yang ditimbulkan dari karyawan satu ke karyawan lainnya menyebabkan motivasi tidak muncul dalam diri karyawan berpengaruh tidak signifikan terhadap karyawan tidak peduli dengan kualitas pelayanan bagi pelanggannya jika dilihat dari jawaban responden dalam kuesioner penelitan.

4. Terbukti tidak signifikan variabel Kepemimpinan (X1) terhadap variabel Kualitas Pelayanan (Y). Variabel Kepemimpinan berhubungan tidak 
signifikan dengan variabel Kualitas Pelayanan karena dengan pimpinan yang tidak mau menerima pendapat karyawan maka karyawan juga tidak mau tahu urusan dengan pelanggan jika dilihat dari distribusi jawaban responden atas pernyataan dalam kuesioner penelitian.

5. Terbukti signifikan bahwa variabel Budaya Organisasi (X2) terhadap variabel Kualitas Pelayanan (Y). Budaya organisasi yang berlangsung adalah karyawan mampu menyelesaikan rencana kerja, bertujuan demi terlaksananya pelayanan terbaik bagi pelanggan. Hal ini menjadi bukti bahwa budaya organisasi berhubungan signifikan terhadap kualitas pelayanan. Tanpa adanya budaya organisasi yang diterapkan di perusahaan dengan baik maka tidak akan ada pelayanan yang terbaik pula bagi pelanggan jika dilihat dari distribusi jawaban responden atas pernyataan dalam kuesioner penelitian.

\section{Saran}

Saran-saran yang dapat diberikan berkaitan dengan Kepemimpinan, Budaya Organisasi dan Motivasi terhadap Kualitas Pelayanan, yaitu:

1. Bagi Organisasi PT. Hadeka Primantara :

a. Pemimpin dalam perusahaan diharapkan dapat memberikan motivasi agar karyawan terdorong dalam peningkatan gairah kerja dengan memberikan segenap kemampuan dan keterampilan demi mewujudkan tujuan perusahaan.

b. Karyawan sebaiknya dapat mengikuti budaya organisasi yang telah ada di perusahaan agar mampu meningkatkan kinerja serta pelayanan terbaik bagi pelanggan.

c. Pemimpin diharapkan mau menerima masukan karyawan demi peningkatan kualitas perusahaan terlebih hubungan perusahaan dengan para pelanggan.

2. Bagi peneliti selanjutnya :

a. Peneliti selanjutnya diharapkan mampu melakukan penelitian dengan menambah variabel penelitian karena masih ada $41,7 \%$ dalam penelitian ini yang dapat dijelaskan oleh variabel lain.

b. Peneliti selanjutnya disarankan untuk menambah metode laindalam meneliti Kualitas Pelayanan, misalnya wawancara mendalam terhadap karyawan, pimpinan dan pelanggan. Sehingga informasi yang diperoleh lebih bervariasi dan lengkap dibandingkan dengan angket yang jawabannya telah tersedia.

\section{REFERENSI}

Sutrisno, Edy. 2015. "Budaya Organisasi”. Jakarta: Kencana Prenadamedia Group. 
Sutrisno, Edy. 2017. "Manajemen Sumber Daya Manusia”. Jakarta: Kencana Prenadamedia Group.

Edison, Emron, Yohny Anwar, dan Imas Komariyah. 2017."Manajemen Sumber Daya Manusia”. Bandung: Alfabeta.

Mulyadi, 2016. "Pengantar Manajemen". Bogor: In Media.

Wibowo. 2013."Budaya Organisasi Sebuah Kebutuhan Untuk Meningkatkan Kinerja Jangka Panjang”. Jakarta: PT. RajaGrafindo Persada.

Prabu Mangkunegara, Anwar. 2001. "Manajemen Sumber Daya Manusia Perusahaan”. Bandung: PT. Remaja Rosdakarya.

Imam Wahjono, Sentot. 2010."Perilaku Organisasi".Yogyakarta: Graha Ilmu.

Dimas, Reza Sigit. 2014."Pengaruh Pelayanan Terhadap Kepuasan Pelanggan Pengguna Jasa Lapangan Futsal (Studi Pada IFI Futsal Bandung)”. Jurnal Fakultas Ekonomi dan Bisnis Universitas Telkom, September 2014.

Marpaung, N. N. (2021). PENGARUH KUALITAS PELAYANAN DAN HARGA TERHADAP KEPUTUSAN PEMBELIAN AIR MINUM ISI ULANG "BIRU” DI JL. JEMBATAN 5 PONDOK TIMUR - KOTA BEKASI. PARAMETER, 5(1), 12-25. https://doi.org/10.37751/parameter.v $5 \mathrm{i} 1.136$

Yusuf, M., Teknologi, I., \& Rakyat, B. (2022). EFEECT OF SHARIA COMPLAINCE, GOVERNANCE, AND SOCISL RESPONSIBILITY ON BUSINESS SUSTAINABILITY : MEDIATING ROLE OF BUSNIESS
GROWTH. 28(1), 2686.

Edison, Emron, Yohny Anwar, dan Imas Komariyah. 2017."Manajemen Sumber Daya Manusia". Bandung: Alfabeta.

Sutrisno, Edy. 2015. "Budaya Organisasi”. Jakarta: Kencana Prenadamedia Group. 